\title{
Silken-fungus beetles (Cryptophagidae, Coleoptera) of the Ukrainian Carpathians
}

\section{Kateryna Ocheretna}

\author{
Institute of Zoology NAS of Ukraine (Kyiv, Ukraine) \\ Kyivo-Pecherskiy Lycee No. 171 "Leader" (Kyiv, Ukraine)
}

\begin{abstract}
Silken-fungus beetles (Cryptophagidae, Coleoptera) of the Ukrainian Carpathians. - Kateryna Ocheretna. - The results of the revision of taxonomy and species richness of silken-fungus beetles of the Ukrainian Carpathians are presented. In the scope of work, all taxonomic and faunistic summaries of the group from 1820 to current studies are included. Three groups of sources are chosen as basis: the author's original research, analysis of collections of natural history museums, and analysis of literature. Considerable attention is paid to taxonomic changes due to which a variety of synonymic names appeared. A short annotation on species richness and on the most important changes in recent taxonomy is given for genera and subgenera, as well as brief information for each species on actual collected specimens. Estimations of species abundance and key biotopes or altitudinal zones, statuses of presence and possible rarity are given. The indices of actual and expected richness of silken-fungus beetles are specified by systematic groups, which showed the highest richness for two genera - Atomaria (50 species belonging to the two subgenera - Atomaria and Agathengis) and Cryptophagus (44 species). On the other hand, 4 genera are monotypic, of which Spavius, Pteryngium, Paramecosoma, and Ootypus are monotypic worldwide, whereas Sternodea is represented only by one species in the Carpathian region (S. baudii). Of the total number of species (116) indicated by different literature sources and actual records for Ukraine, the presence of 78 species is confirmed by the author's original records and results of analysis of zoological collections. The remaining 38 species are indicated by ambiguous records in the literature (including adjacent countries) and they are not confirmed by descriptions or collection specimens. Eight species representing the genera Antherophagus (1), Atomaria (2), and Cryptophagus (5) are given for the region's fauna for the first time. It is shown that the largest number of species and genera is common for forsted piedmont areas, and less so for high elevations. An increase in the number of species is expected in case of further research in Bukovina and, in general, in the northeastern macroslopes of the Carpathians.
\end{abstract}

Key words: silken-fungus beetles, biodiversity, fauna checklist, taxonomy, Ukrainian Carpathians.

\section{Introduction}

The silken-fungus beetles are closely associated to forest ecosystems of piedmont and mountainous regions. They are often considered within the groups of saproxylic and xylobiont Coleoptera (Buse 2009), as the main substrate for such genera as Cryptophagus and Atomaria is wood-decay fungi and molds. Nevertheless, neither the silken-fungus beetles nor data about their occurrence in the region have been listed yet in the European Red List of Saproxylic Beetles (Nieto 2010), although many rare species of the family should be included in the List along with species that are closely related to cryptophagids trophically (Erotylidae, Languriidae, and Mycetophagidae), which are listed there. The silken-fungus beetles and the two mentioned families are associated with the fruit bodies of various fungi (basidiomycetes, deuteromycetes, ascomycetes, etc.) as a substrate they dwell and feed on (Carpaneto 2015).

The creation of checklists is an important step in the study of each systematic group in any region. For the superfamily Cucujoidea, a cheklist was prepared by V. Tsinkevich (Tsinkevich 2005), which contains the families Cryptophagidae, Nitidulidae, Monotomidae, and others. The author of this article prepared a list of species of the genus Cryptophagus, distributed in the Borzhava massif, i.e. in Volovets and Mizhhirya Raions of Zakarpattia Oblast (Liashyna 2018).

The idea of checklists is long-standing, but it has become relevant after the implementation of the Convention on Biological Diversity (Convention... 1992), one of the key ideas of which is the Global

Correspondence to: Kateryna Ocheretna; Kyivo-Pecherskiy Lycee No. 171 "Leader"; Leipzigska St. 11 A, Kyiv, 01015 Ukraine; e-mail: kateryna_ocheretna@ukr.net; orcid: 0000-0002-7759-8878 
Taxonomy Initiative (Global... 2018). This topic is relevant for Ukraine, and it is based on the development of monitoring programs for the protection and rational use of biological resources, where the key point is the creation of detailed and verified checklists of the regional fauna, indicating various statuses of a species (rarity, invasiveness, migratory activity, belonging to the lists of special attention, industrial species, pests, etc.). Such lists of the existing diversity are especially valuable in relation to large natural regions with a high level of conservation of natural landscapes and, at the same time, with a high level of economic and recreational use, as well as for groups with species diversity of hundreds of species. Therefore, the object of the author's research, which is the silken-fungus beetles of the Carpathians, completely meets the tasks of the GTI.

The problem in estimation of the diversity of this group of beetles is their insignificant representation in natural history collections in Ukraine. The same can be notified for the literature sources: most of the available information on the distribution and number of species is limited to extrapolated data from neighbouring regions, which, in particular, we see in current lists of the web-resource "Fauna Europaea" (Otero et al. 2018).

The main aim of the work is to compile a systematic list of silken-fungus beetles of the Ukrainian Carpathians based on results of original research, analysis of collections of natural history museums of Ukraine and information from the literature.

\section{Materials and Methods}

The study covers the period from the first to the present faunal reports concerning Cryptophagidae. The main features of body structure of this group of beetles are presented by J. Roubal, M. Nowicki, O. Marcu and other researchers. An overview of such summaries is presented below.

Materials from the following collections are analysed: 1) the author's collection (planned to be transferred for permanent storage to one of the museums) (1657 specimens, 57 species from the Carpathian region) (Liashyna 2016, 2018, 2019); 2) collection of the State Museum of Natural History NAS of Ukraine (224 specimens, 15 species from the territory of the Carpathians) (Ocheretna 2019 b); 3) collection of the National Museum of Natural History NAS of Ukraine (214 specimens, no specimens from the Carpathians) (Ocheretna $2019 d-e)$, 4) collection of the Zoological Museum of Taras Shevchenko National University of Kyiv (304 specimens, 23 species from the territory of the Carpathians) (Ocheretna 2019a); 5) collection of the State Museum of Nature of V. N. Karazin Kharkiv National University (341 specimens, 9 species from the Carpathian region, 7 of which are collected in the mountains of Zakarpattia Oblast) and 6) V. Lazorko's collection stored at I. I. Schmalhausen Institute of Zoology NAS of Ukraine (Kyiv) (263 specimens, 17 species from the Carpathian region) (Ocheretna 2019 c). Designation of collections in the descriptions of species in the order of guidance here: SMNH, KOC, NMNH, ZMKU, MNKU, SIZK. The characteristics of the collections are given below in a separate section.

The collections contain from 21 to 57 species of Cryptophagidae. For example, the author's collection contains 57 Carpathian species, V. Lazorko's collection contains 17 Carpathian species, 48 species in total, and the third important is the ZMKU collection (23 species of 85 in total). A detailed analysis of the collections was presented earlier (Ocheretna $2019 a-d$ ).

The original research was conducted during 2015-2018, mainly in the spring and autumn in 40 locations in vicinities of Uzhhorod city and in Perechyn, Mizhhirya, Tyachiv, Uzhhorod, Volovets, and Velykyi Bereznyi Raions. In total, about 1700 specimens were collected, representing 57 species from 13 genera. All of the material is mounted, partially stored on mattresses with proper labels.

The material was identified using the appropriate keys (Reitter 1909; Reška 1994; Otero 2013) and the nomenclature follows the catalogue of beetles by I. Löbl and A. Smetana (2007) for the Palearctic. The works of H. Freude, R. Leschen, G. Lyubarsky (Freude 1967; Leschen 1996; Lyubarsky 1998, 2002) are used to clarify the taxonomy (in particular, the division of the family into genera and suprageneral groups). G. Lyubarsky's reviews (Lyubarsky 1998, 2002) are taken as a basis for the taxonomic 
scheme of subfamilies. The taxa are listed in alphabetical order: within the family and each smaller taxon. The volume of tribes is given according to Leschen (Leschen 1996). Data on the number of species in genera are given according to G. Lyubarsky (Lyubarsky 2002).

Annotations were prepared for each genus and subgenus, the obligatory parts of which are the following information: information on the most important changes in the taxonomy and nomenclature (first of all, in comparison with the summaries of the 1930s-1940s (Roubal 1930, 1936, 1941), information on the volume of the genus or subgenus and the availability of relevant revisions (Lyubarsky 1998), distribution, preferred biotopes, features of ontogenesis, biology, and life cycles (Burakowski et al. $1986 a-b, 1987)$.

For each species, brief information on collection specimens is given. In fact, the availability of collection specimens was a key criterion for including a species into the fauna checklist. In some cases, when the taxonomy and nomenclature of a certain group of species did not change significantly, and the presence of a species can be claimed from the descriptions, literature references are taken into account. However, the author verified the species identification in all cases.

\section{Characteristics of key articles and collections}

The section provides a brief description of the most important reviews and collections. These two groups of sources (scientific publications and zoological collections) are an important addition to the original data, and, in some cases, the only possible source for estimation of the presence and distribution (or frequency) of a species in the Ukrainian Carpathians.

The article includes scientific papers which contain the information on Cryptophagidae species which are recorded in the territory of modern Ukraine and in the Carpathian region. In some cases, the presence of species in the region cannot be stated unequivocally; some researchers omitted indications of specific locations or due to the fact that the borders of Ukraine, Poland, Slovakia, and Romania underwent several changes. Subject to this caveat, all of the following species are considered to be part of the fauna of the Ukrainian Carpathians. In all cases, when mentioning the region, we are talking about the Ukrainian part of the Carpathians, i.e. the Eastern Carpathians within the modern territory of Ukraine.

The sources for the presence of species in the region's fauna, which are given after the species name, are based on works of the following researchers: J. Roubal (Roubal 1930, 1936, 1941) (Slovakia and Carpathian Ruthenia, the most of modern Zakarpattia Oblast), M. Łomnicki (Łomnicki 1875, 1886, 1913) (territory of Poland and parts of modern Lviv Oblast), M. Nowicki (Nowicki 1864, 1865, 1873) (territory of Galicia: parts of modern Lviv, Ivano-Frankivsk and Ternopil Oblasts of Ukraine, Subcarpathian and most of Lesser Poland Voivodeship of Poland), J. Müller (Müller 1862) (territory of Austrian Silesia (northeastern part of modern Bohemia), S. Tenenbaum (Tenenbaum 1913, 1923, 1938) (territory of Poland), O. Marcu (Marcu $1928 a-b, 1929,1930)$ (territory of Bukovina, AustriaHungary, and modern Romania), L. Miller (Miller 1867) (territory of the eastern part of Galicia).

\section{Checklist}

The Cryptophagidae family belongs to the superfamily Cucujoidea and includes about 700 species, according to some sources - about 1000 (Peris 2017), belonging to 3 subfamilies, 4 tribes, and 54 genera, which are common in all biogeographical regions. During the original research, 57 species were identified (Liashyna 2016, 2018, 2019), which belong to 13 genera with 3 subfamilies and 4 tribes - Atomariini, Caenoscelini, Cryptophagini, and Telmatophilini (Table 1).

A new series of studies with the revision of all literature data and collections gave a larger number of species - 116 species from 14 genera for the Carpathian region, whereas the total number of species for Ukraine is 122 (representing 16 genera, respectively) (Ocheretna 2019 b). Of 116 species, 8 species (genera Antherophagus (1), Atomaria (2), Cryptophagus (5)) have not previously been reported in the literature for the region's fauna. Those include 3 species from the author's collection and 
5 from the museums. A detailed description of such additions to the fauna of the region is presented in a separate paper (Ocheretna $2019 b$ ).

Adult beetles and larvae are predominantly mycetophages and feed on rotting plant debris and fungi. Cryptophagidae are commonly found in damp places, under bark, in forest litter, topsoil, in nests of bumblebees, wasps, ants, as well as in cellars, warehouses, and in moldy products. Some species are pests that damage the seeds and seedlings of beets and turnips (e.g. Atomaria linearis Stephens, 1830).

Asterisk $\left(^{*}\right)$ signed before the species name is given to highlight the species which are not mentioned for the Carpathians in any of the revised publications.

Table 1. Distribution of Cryptophagidae genera known in the Ukrainian Carpathian fauna by supergeneric taxa and indices of their species richness based on the author's original research (column 2016) and on results of the analysis of the entire volume of collections and publications (column 2019)

Таблиия 1. Розподіл родів родини криптофагід, відомих у фауні Украӥнських Карпат, за надродовими таксонами та показники їхнього видового багатства за матеріалами оригінальних досліджень автора (колонка 2016) та підсумками аналізу всього обсягу колекцій та публікацій (колонка 2019)

\begin{tabular}{|c|c|c|c|c|}
\hline Subfamily & Tribe & Genus & $\begin{array}{c}\text { Number of } \\
\text { species, } 2016\end{array}$ & $\begin{array}{c}\text { Number of } \\
\text { species, } 2019\end{array}$ \\
\hline \multirow[t]{4}{*}{ Atomariinae } & \multirow[t]{4}{*}{ Atomariini Le Conte, 1861} & Atomaria Stephens, 1829 & 16 & 50 \\
\hline & & Curelius Casey, 1900 & 1 & 1 \\
\hline & & Ephistemus Stephens, 1829 & 0 & 1 \\
\hline & & Ootypus Ganglbauer, 1899 & 1 & 1 \\
\hline \multirow[t]{10}{*}{ Cryptophaginae } & \multirow[t]{2}{*}{ Caenoscelini Casey, 1900} & Caenoscelis Thomson, 1863 & 1 & 3 \\
\hline & & Sternodea Reitter, 1875 & 1 & 1 \\
\hline & \multirow[t]{8}{*}{ Cryptophagini Kirby, 1826} & Antherophagus Dejean, 1821 & 3 & 3 \\
\hline & & Cryptophagus Herbst, 1792 & 23 & 44 \\
\hline & & Henoticus Thomson, 1868 & 1 & 1 \\
\hline & & Hypocoprus Motschulsky, 1839 & 0 & 1 \\
\hline & & Micrambe Thomson, 1863 & 2 & 3 \\
\hline & & Paramecosoma Curtis, 1833 & 1 & 1 \\
\hline & & Pteryngium Reitter, 1887 & 1 & 1 \\
\hline & & Spavius Stål, 1862 & 1 & 1 \\
\hline Telmatophilinae & Telmatophilini Jacquelin du Val, 1858 & Telmatophilus Heer, 1841 & 2 & 4 \\
\hline In total & & & 54 sp., 13 gen. & 116 sp., 14 gen. \\
\hline
\end{tabular}

\section{Genus Antherophagus Dejean, 1821}

Taxonomy. There are at least 13 species in this genus. In Ukrainian Carpathians, we found 3 species. Distribution. Species are found in the southern part of Northern Europe and in Central Europe, reaching southern central France and northern Italy, marked in Poland and Ukraine. Occur in the nests of bumblebees and in the period of vegetation on flowers that grow in moist places on meadows and forest edges, especially on flowering raspberries. They attach themselves to the body of bumblebees with the help of heavily developed mandibles; in the nests of the representatives Bombus Latreille, 1802 (and other genera) their larvae can completely develop.

Antherophagus pallens (Fabricius, 1781)

Col.: SMNH, MNKU, KOC; Lit.: Müller 1862 (Antherophagus nigricornis and A. pallens); Miller 1867 (A. nigricornis); Łomnicki 1868 (A. nigricornis); Nowicki 1873 (A. nigricornis and A. pallens); Łomnicki 1886 (A. nigricornis); Łomnicki 1890 (A. nigricornis and A. pallens); Łomnicki 1913 (A. nigricornis and A. pallens); Tenenbaum 1913 (A. nigricornis and A. pallens); Marcu 1928 a (A. nigricornis); Marcu 1928 b; Roubal 1936 (A. nigricornis, A. nigricornis f. fascifera and A. pallens).

Antherophagus silaceus (Herbst, 1792)

Col.: MNKU, KOC; Lit.: Müller 1862; Nowicki 1864, 1865, 1873; Łomnicki 1866, 1875, 1886, 1913;

Tenenbaum 1913; Roubal 1936 (Antherophagus canescens).

${ }^{*}$ Antherophagus similis Curtis, 1835

Col.: MNKU, KOC. 


\section{Genus Atomaria Stephens, 1829}

Taxonomy. More than 200 species and 2 subgenera; in the fauna of the Ukrainian Carpathians 50 species, including 21 species of the Agathengis subgenus and 29 species of nominative subgenus.

Distribution. South Palaearctic species occur in Europe from the Mediterranean to England and the southern provinces of Fennoscandia, Poland, and Russia. In Ukraine, they are spread throughout the territory. In the Carpathians, inhabit mainly the woods: in the litter, under the ground and in the fruit bodies of fungi. The species of Atomaria mostly live in mouldy substrates, more rarely in debris, dried dung, on fungi or on the twigs. They are active flyers and are regularly collected at light.

\section{Subgenus Agathengis Des Gozis, 1886}

Atomaria (A.) affinis Sahlberg, 1834

Col.: KOC; Lit.: Łomnicki 1913; Marcu 1936; Roubal 1936.

Atomaria (A.) alpina Heer, 1841

Col.: KOC; Lit.: Łomnicki 1913; Roubal 1936 (Atomaria alpina and A. alpina a. scharpi).

Atomaria (A.) atrata Reitter, 1875

Col.: KOC; Lit.: Roubal 1936 (Atomaria prolixa f. atrata).

Atomaria (A.) barani C. Brisout de Barneville, 1863

Col.: no; Lit.: Łomnicki 1913; Roubal 1936.

Atomaria (A.) bella Reitter, 1875

Col.: SIZK; Lit.: Łomnicki 1913; Roubal 1936.

Atomaria (A.) bescidica Reitter, 1888

Col.: no; Lit.: Łomnicki 1913; Roubal 1936.

Atomaria (A.) bicolor Erichson, 1846

Col.: ZMKU; Lit.: Łomnicki 1913; Roubal 1936 (Atomaria bicolor and A. acutifrons).

Atomaria (A.) carpathica Reitter, 1875

Col.: KOC, SIZK; Lit.: Łomnicki 1913; Roubal 1936.

Atomaria (A.) diluta Erichson, 1846

Col.: SMNH, KOC; Lit.: Łomnicki 1913; Roubal 1936.

Atomaria (A.) elongatula Erichson, 1846

Col.: KOC; Lit.: Nowicki 1873.

Atomaria (A.) fimetarius (Fabricius, 1792)

Col.: ZMKU, KOC; Lit.: Łomnicki 1913 (Grobbenia fimetarii a. flavescens, G. fimetarii a. brunnea, G. fimetarii

a. opaca); Marcu 1936 (Grobbenia fimetarii); Roubal 1936 (Atomaria fimetarii, A. fimetarii f. brunnea and A. fimerii f. flavescens).

Atomaria (A.) impressa Erichson, 1846

Col.: n/a; Lit.: Łomnicki 1913; Roubal 1936.

Atomaria (A.) linearis Stephens, 1830

Col.: ZMKU, KOC, SIZK; Lit.: Müller 1862; Miller 1867; Nowicki 1873; Łomnicki 1875, 1886, 1890, 1913; Roubal 1936.

Atomaria (A.) longicornis C. G. Thomson, 1863

Col.: n/a; Lit.: Łomnicki 1913 (Atomaria procerula); Roubal, 1936 (Atomaria procerula).

Atomaria (A.) nigrirostris Stephens, 1830

Col.: ZMKU, KOC, SIZK; Lit.: Łomnicki 1913 (Atomaria fuscicollis); Roubal 1936 (A. fuscionis).

Atomaria (A.) nigriventris Stephens, 1830

Col.: n/a; Lit.: Łomnicki, 1890, Roubal 1936. 
Atomaria (A.) norica Ganglbauer, 1899

Col.: n/a; Lit.: Miller 1867 (Atomaria nana); Nowicki 1873 (Atomaria nana); Łomnicki 1875 (Atomaria nana).

Atomaria (A.) puncticollis Thomson, 1868

Col.: KOC; Lit.: Łomnicki 1913 (Atomaria nigriventris f. puncticollis); Roubal 1936 (A. nigriventris f. puncticollis)

Atomaria (A.) pulchra Erichson, 1846

Col.: SIZK; Lit.: Łomnicki 1913 (Atomaria prolixa v. atrata, and A. pulchra); Roubal 1936 (A. prolixa, A. prolixa f. pulchra and A. prolixa f. atrata).

${ }^{\star}$ Atomaria (A.) soror Ganglbauer, 1899

Col.: SIZK.

Atomaria (A.) umbrina (Gyllenhal, 1827)

Col.: ZMKU, KOC, SIZK; Lit.: Müller 1862; Miller 1867; Nowicki 1873; Łomnicki 1875, 1890, 1913 (Atomaria pumila and A. umbrina); Tenenbaum 1923 (A. pumila); Marcu 1936; Roubal 1936.

\section{Subgenus Atomaria (s. str.) Stephens, 1829}

Atomaria (A.) analis Erichson, 1846

Col.: ZMKU, SMNH, KOC; Lit.: Müller 1862; Miller 1867; Nowicki 1873; Łomnicki 1875, 1913; Roubal 1936.

Atomaria (A.) apicalis Erichson, 1846

Col.: ZMKU, SMNH, KOC, SIZK; Lit.: Müller 1862; Łomnicki 1877, 1890, 1913; Roubal 1936.

Atomaria (A.) atra (Herbst, 1793)

Col.: KOC, SIZK; Lit.: Łomnicki 1890, 1891, 1913; Roubal 1936.

Atomaria (A.) atricapilla Stephens, 1830

Col.: SMNH; Lit.: Müller 1862; Łomnicki 1891, 1913; Roubal 1936.

Atomaria (A.) attila Reitter, 1878

Col.: KOC; Lit.: Łomnicki 1913; Roubal 1936 (Atomaria attila, A. attila f. banatica and A. attila f. flavicolor).

Atomaria (A.) basalis Erichson, 1846

Col.: n/a; Lit.: Łomnicki 1870; Nowicki 1873.

Atomaria (A.) clavigera Ganglbauer, 1899

Col.: n/a; Lit.: Łomnicki 1913 (Atomaria clavipes); Roubal 1936.

Atomaria (A.) fuscata (Schönherr, 1808)

Col.: ZMKU, SMNH, KOC, SIZK; Lit.: Łomnicki 1866, 1870 (Atomaria fuscula); Łomnicki 1875, 1886, 1890, 1913; Tenenbaum 1913; Roubal 1936.

Atomaria (A.) fuscipes (Gyllenhal, 1808)

Col.: KOC; Lit.: Müller 1862; Nowicki 1873; Łomnicki 1875, 1886, 1913; Roubal 1936.

Atomaria (A.) gibbula Erichson, 1846

Col.: n/a; Lit.: Müller 1862; Łomnicki, 1913; Marcu 1928 a (Anchicera gibbula); Roubal 1936.

Atomaria (A.) gravidula Erichson, 1846

Col.: ZMKU; Lit.: Müller 1862; Łomnicki 1913; Marcu 1928 a (Anchicera gravidula); Roubal 1936 (Atomaria gravidula and $A$. formosa).

Atomaria (A.) gutta Newman, 1834

Col.: n/a; Lit.: Łomnicki 1870, 1886, 1913; Nowicki 1873; Roubal 1936.

Atomaria (A.) mesomela (Herbst, 1792)

Col.: n/a; Lit.: Tenenbaum 1913 (Atomaria mesomelaena); Łomnicki 1913 (Atomaria mesomelaena v. guttula and A. mesomelaena a. pseudoatra); Marcu 1930 (Anchicera mesomelaena); Roubal 1936 (Atomaria mesomelaena). 
Atomaria (A.) morio Kolenati, 1846

Col.: n/a; Lit.: Łomnicki 1913; Roubal 1936.

Atomaria (A.) munda Erichson, 1846

Col.: n/a; Lit.: Nowicki 1873; Łomnicki 1866, 1913; Roubal 1936.

Atomaria (A.) nigripennis (Kugelann, 1794)

Col.: n/a; Lit.: Łomnicki 1886 (Atomaria pulchella); Łomnicki 1890 (A. pulchella); Łomnicki 1913; Marcu 1931 (Anchicera nigripennis); Marcu 1936.

Atomaria (A.) nitidula Marsham, 1802

Col.: n/a; Lit.: Łomnicki 1886, 1913; Roubal 1936.

Atomaria (A.) ornata Heer, 1841

Col.: n/a; Lit.: Łomnicki 1913; Roubal 1936.

Atomaria (A.) peltata Kraatz, 1853

Col.: n/a; Lit.: Łomnicki 1875, 1877, 1913; Roubal 1936.

Atomaria (A.) plicata Reitter, 1875

Col.: n/a; Lit.: Łomnicki 1913; Roubal 1936 (Atomaria plicata and A. plicata f. amplipennis).

Atomaria (A.) pusilla (Paykull, 1798)

Col.: KOC; Lit.: Müller 1862; Łomnicki 1870, 1886, 1890, 1913; Nowicki 1873; Roubal 1936.

${ }^{*}$ Atomaria (A.) rubella Heer, 1841

Col.: SIZK.

Atomaria (A.) rubida Reitter, 1875

Col.: n/a; Lit.: Łomnicki 1913 (Atomaria cognata); Roubal 1936 (A. viennensis and A. viennensis f. rubida).

Atomaria (A.) scutellaris (Motschulsky, 1849)

Col.: n/a; Lit.: Roubal 1936.

Atomaria (A.) testacea Stephens, 1830

Col.: KOC; Lit.: Müller 1862 (Atomaria ruficornis); Łomnicki 1870 (A. terminata); Nowicki 1873

(A. terminata); Łomnicki 1875 (A. ruficornis); Łomnicki 1886 (A. ruficornis and A. testacea), Łomnicki 1890

(A. ruficornis and A. testacea); Łomnicki 1913 (A. ruficornis v. nigricornis); Roubal 1936 (A. ruficornis).

Atomaria (A.) turgida Erichson, 1846

Col.: SMNH; Lit.: Łomnicki 1886, 1913; Marcu 1933; Roubal 1936.

Atomaria (A.) unifasciata Erichson, 1846

Col.: n/a; Lit.: Müller 1862; Tenenbaum 1923; Roubal 1936.

Atomaria (A.) versicolor Erichson, 1846

Col.: n/a; Lit.: Łomnicki 1913; Tenenbaum 1923; Roubal 1936.

Atomaria (A.) zetterstedti (Zetterstedt, 1838)

Col.: n/a; Lit.: Łomnicki 1913; Roubal 1936.

Genus Caenoscelis Thomson, 1863

Taxonomy. Twelve described species; in the fauna of the Carpathians -3 species, including the information from literature sources.

Distribution. Species of the genus are spread from England and France through Northern and Central Europe to the eastern part of Siberia; to the south reach Serbia, Transylvania, and the Caucasus, in Poland they are distributed in the south, in Ukraine mostly in the west. They can be found year-round in rotten and moldy stumps and trunks, rotting leaves, mixed with thickets and pieces of wood, in old stacks of sawdust near sawmill and under moldy bark; in addition, are caught under trees and during flights. 
Caenoscelis ferruginea (Sahlberg, 1820)

Col.: KOC; Lit.: Łomnicki 1913; Roubal 1936.

Caenoscelis sibirica Reitter, 1889

Col.: n/a; Lit.: Roubal 1936 (Caenoscelis Fleischeri).

Caenoscelis subdeplanata C. Brisout de Barneville, 1882

Col.: n/a; Lit.: Łomnicki 1913; Roubal 1936.

\section{Genus Cryptophagus Herbst, 1863}

Taxonomy. Approximately 250 species, 44 are known from the Carpathians in collections, but only 23 were recorded by the author in the Ukrainian Carpathians.

Distribution. Distributed across all ecozones of the world (Lyubarsky 2011), known in Europe, Greenland, Asia, Africa, and North America. These beetles can be found in other habitats where fungi are available, such as beehives, the nests of other hymenopterans such as wasps and ants, rodent burrows, and wool (Lyubarsky 2012). As most of the other beetles of the family, these are fungivores, feeding on fungal spores and hyphae. Some species are considered pests: they inhabit grain stores, flour, bread, dried fruit, and other products, however, the beetles feed on fungi that grow on the food product rather than on the product itself. They also breed in the fungi laying eggs in the hyphae. They are more common in products that are damp and moldy. The beetles can transmit fungal spores to products enhancing mold growth.

Cryptophagus acutangulus Gyllenhal, 1827

Col.: ZMKU, KOC, SIZK; Lit.: Müller 1862; Nowicki 1864, 1865, 1873; Łomnicki 1866, 1875, 1886, 1890, 1913; Roubal 1936.

\section{Cryptophagus axillaris Reitter, 1875}

Col.: ZMKU, KOC; Lit.: Roubal 1936 (subspecies Cryptophagus (Mnionomus) axillaris).

Cryptophagus badius Sturm, 1845

Col.: SIZK; Lit.: Łomnicki 1913; Marcu 1936; Roubal 1936.

Cryptophagus baldensis Erichson, 1846

Col.: n/a; Lit.: Łomnicki 1913; Roubal 1936 (subspecies Cryptophagus (Mnionomus) baldensis).

Cryptophagus cellaris (Scopoli, 1763)

Col.: n/a; Lit.: Łomnicki 1866, 1875, 1886 (Cryptophagus crenatus and C. cellaris); Nowicki 1873; Łomnicki 1890, 1913; Roubal 1936.

Cryptophagus confusus Bruce, 1934

Col.: n/a; Lit.: Tenenbaum 1938.

Cryptophagus croaticus Reitter, 1879

Col.: n/a; Lit.: Łomnicki 1913; Roubal 1936 (subspecies Cryptophagus (Mnionomus) croaticus and as subspecies $C$. (M.) croaticus var. tridentatus).

Cryptophagus cylindrellus Johnson, 2007

Col.: n/a; Lit.: Łomnicki 1913 (Cryptophagus cylindrus); Tenenbaum 1913 (C. cylindrus); Roubal 1936 (C. cylindrus).

Cryptophagus dentatus (Herbst, 1793)

Col.: ZMKU, SMNH, KOC; Lit.: Müller 1862 (Cryptophagus fumatus and C. dentatus); Miller 1867; Nowicki 1873; Łomnicki 1868, 1875, 1886, 1890, 1913 (C. fumatus and C. dentatus); Roubal 1936 (C. fumatus); Tenenbaum 1913.

${ }^{*}$ Cryptophagus denticulatus Heer, 1841

Col.: SIZK.

${ }^{\star}$ Cryptophagus dilutus Reitter, 1874

Col.: KOC. 


\section{Cryptophagus distinguendus Sturm, 1845}

Col.: KOC, SIZK; Lit.: Müller 1862; Nowicki 1865, 1873; Łomnicki 1866, 1886, 1890, 1913 (Cryptophagus distinguendus and C. umbratus); Roubal 1936 (C. distinguendus and C. umbratus).

Cryptophagus dorsalis C. R. Sahlberg, 1819

Col.: n/a; Lit.: Łomnicki 1886, 1913, Roubal 1936.

\section{Cryptophagus fallax Balfour-Browne, 1953}

Col.: SIZK; Lit.: Łomnicki 1875 (Cryptophagus fumatus); Łomnicki 1886 (C. fumatus).

Cryptophagus falcozi Roubal, 1927

Col.: SIZK; Lit.: Roubal 1936.

Cryptophagus fasciatus Kraatz, 1852

Col.: ZMKU; Lit.: Roubal 1936.

Cryptophagus fuscicornis Sturm, 1845

Col.: ZMKU, KOC; Lit.: Łomnicki 1913; Roubal 1936.

Cryptophagus hexagonalis Tournier, 1872

Col.: n/a; Lit.: Łomnicki 1913 (Cryptophagus subvittatus),

Cryptophagus inaequalis Reitter, 1878

Col.: n/a; Lit.: Łomnicki 1913; Roubal 1936.

Cryptophagus labilis Erichson, 1846

Col.: n/a; Lit.: Łomnicki 1913; Roubal 1936.

Cryptophagus lapponicus Gyllenhal 1827

Col.: KOC; Lit.: Łomnicki 1913 (Cryptophagus lapponicus and C. validus); Roubal 1936 (C. validus).

Cryptophagus laticollis Lucas, 1846

Col.: SMNH, KOC; Lit.: Nowicki 1865, 1873 (Cryptophagus affinis); Łomnicki 1866 (C. affinis); Miller 1867 (C. affinis); Łomnicki 1868 (C. affinis); Łomnicki 1886 (C. affinis); Łomnicki 1913 (C. affinis and C. Milleri); Roubal 1936 (C. affinis).

Cryptophagus lycoperdi (Scopoli, 1763)

Col.: KOC; Lit.: Müller 1862; Łomnicki 1886, 1890, 1913; Tenenbaum 1913; Marcu 1936; Roubal 1936.

${ }^{\star}$ Cryptophagus lysholmi Munster, 1932

Col.: SIZK.

${ }^{*}$ Cryptophagus micaceus Rey, 1889

Col.: KOC.

Cryptophagus montanus C. Brisout, 1863

Col.: ZMKU, KOC; Lit.: Łomnicki 1913 (Cryptophagus silesiacus and C. deubeli); Roubal 1936 (subspecies Cryptophagus (Mnionomus) deubeli, Cryptophagus (Mnionomus) transsylvanicus та C. (Mnionomus) silesiacus).

Cryptophagus nitidulus Miller, 1858

Col.: KOC, Lit.: Roubal 1936 (as separate subgenus Cryptophagus (Mnionomus) nitidulus); Tenenbaum 1938.

Cryptophagus pallidus Sturm, 1845

Col.: ZMKU, KOC; Lit.: Łomnicki 1913 (Cryptophagus pallidus and C. thomsoni), Tenenbaum 1923; Marcu 1930 (C. thomsoni); Marcu 1936; Roubal 1936 (C. pallidus and C. thomsoni).

Cryptophagus pilosus Gyllenhal, 1827

Col.: SIZK; Lit.: Müller 1862; Miller 1867; Łomnicki 1868, 1870, 1886; Nowicki 1873; Łomnicki 1890 (Cryptophagus pilosus var. punctipennis); Tenenbaum 1913; Łomnicki 1913; Roubal 1936 (C. pilosus and C. pilosus s. punctipennis).

Cryptophagus populi Paykull, 1800

Col.: n/a; Lit.: Łomnicki 1913 (Cryptophagus populi v. grandis); Tenenbaum 1923; Roubal 1936. 


\section{Cryptophagus pubescens Sturm, 1845}

Col.: n/a; Lit.: Müller 1862; Łomnicki 1913; Marcu 1936; Roubal 1936.

Cryptophagus punctipennis Brisout, 1863

Col.: KOC; Lit.: Łomnicki 1913; Roubal 1936.

Cryptophagus quercinus Kraatz, 1852

Col.: KOC; Lit.: Łomnicki 1886, 1913, Roubal 1936.

Cryptophagus reflexicollis Reitter, 1876

Col.: SMNH, KOC; Lit.: Łomnicki 1913; Roubal 1936 (as separate subgenus Cryptophagus (Mnionomus) reflexicollis).

${ }^{*}$ Cryptophagus reflexus Rey, 1889

Col.: KOC.

Cryptophagus saginatus Sturm, 1845

Col.: KOC; Lit.: Müller 1862, Łomnicki 1890, 1913; Roubal 1936.

Cryptophagus scanicus Linnaeus, 1758

Col.: ZMKU, SMNH, KOC, SIZK; Lit.: Müller 1862; Miller 1867; Nowicki 1873, Łomnicki 1868, 1886; Łomnicki 1913 (Cryptophagus scanicus a. patruelis); Tenenbaum 1913; Roubal 1936 (C. scanicus and, separately, C. scanicus f. patruelis).

Cryptophagus schmidti Sturm, 1845

Col.: SIZK; Lit.: Łomnicki 1913; Roubal 1936 (as separate subgenus Cryptophagus (Mnionomus) schmidti).

Cryptophagus scutellatus Newman, 1834

Col.: KOC; Lit.: Łomnicki 1877 (Cryptophagus bicolor); Łomnicki 1886, 1890; Łomnicki 1913 (C. pumilio and C. scutellatus); Tenenbaum, 1913; Roubal, 1936.

Cryptophagus setulosus Sturm, 1845

Col.: ZMKU; Lit.: Nowicki 1873; Łomnicki 1913; Roubal, 1936.

Cryptophagus simplex Miller, 1858

Col.: n/a; Lit.: Łomnicki 1913; Marcu 1936.

Cryptophagus subdepressus Gyllenhal, 1827

Col.: KOC; Lit.: Nowicki 1873; Łomnicki 1913; Roubal 1936.

Cryptophagus subfumatus Kraatz, 1856

Col.: SMNH, KOC; Lit.: Łomnicki 1913; Roubal 1936.

Cryptophagus uncinatus Stephens, 1830

Col.: KOC; Lit.: Łomnicki 1877 (Cryptophagus hirtulus); Łomnicki 1913 (C. hirtulus).

\section{Genus Curelius Casey, 1900}

Taxonomy. There are at least three described species in the genus, but only one occurs in the Carpathians.

Distribution. Found in the Palaearctic. One of the species was found in the Afrotropical Region (Lyubarsky 1999, 2011). Curelius species are common in Central and Southern Europe and in the Caucasus (unknown in the Iberian Peninsula). Often found under fallen leaves, near pasture, in composting barrows, and among rotting straw.

Curelius exiguus (Erichson, 1846)

Col.: KOC; Lit.: Łomnicki 1913 (Ephistemus); Tenenbaum 1923 (Ephistemus); Roubal 1936 (Ephistemus).

\section{Genus Ephistemus Stephens, 1829}

Taxonomy. There are 6 described species worldwide; one species in Carpathians is confirmed by collections and literary sources. 
Distribution. Species are widespread in Europe from the Mediterranean to the British Isles, the southern parts of Norway and Finland, as well as northern Sweden, Russian and Finland Karelia, Central and Eastern Europe, including Ukraine, except the highland areas. Found among rotten plant residues, in fertilizers and under the fallen leaves.

Ephistemus globulus (Paykull, 1798)

Col.: ZMKU, SMNH; Lit.: Müller 1862 (Ephistemus gyrinoides); Miller 1867 (E. gyrinoides); Łomnicki 1870;

Łomnicki 1886 (E. nigriclavis and E. globulus); Nowicki 1873 (E. gyrinoides and E. globulus); Nowicki 1913

(E. globulus var. ovulum, E. globulus var. dimidiatus, E. globulus var. dubius); Roubal 1936 (E. globulus,

E. globulus f. piceorrhoea, E. globulus f. ovulum, E. globulus f. dubia).

\section{Genus Henoticus Thomson, 1868}

Taxonomy. There are about 30 described species in the genus, only one occurs in the Carpathians.

Distribution. Widespread in Europe, from the British Isles, from the extreme parts of northern Fennoscandia, particularly Karelia (both parts) to France, northern Italy, Romania (Transylvania), and Ukraine (Volyn), are registered from the Caucasus, Siberia, North America and the Hawaiian Islands. Species are known from Poland and Ukraine and occur in the spring on willow inflorescences and under the bark of aspen, and in autumn under rotten leaves in mixed forests.

Henoticus serratus (Gyllenhal, 1808)

Col.: MNKU, KOC; Lit.: Müller 1862 (Paramecosoma serratum); Miller 1867 (P. serratum); Łomnicki 1868 (P. serratum); Nowicki 1873 (P. serratum); Łomnicki 1886, 1913; Roubal 1936.

\section{Genus Hypocoprus Motschulsky, 1839}

Taxonomy. Three known species widespread worldwide, one of them could be present in the Carpathians, but have not been confirmed by collected specimens.

Distribution. Species are common in Fennoscandia and found in Ukraine. The only Carpathian species lives in the nests of the Formica ants, especially F. exsecta Nylander (H. latridioides). Also found under dry animal excrements, especially cows, horses and goats.

Hypocoprus latridioides (Motschulsky, 1839)

Lit.: Łomnicki 1886, 1913 (H. quadricollis and H. latridioides).

\section{Genus Micrambe Thomson, 1863}

Taxonomy. The genus contains more than 80 species, 3 species occur in the Carpathians, 2 of them are present in the author's collection.

Distribution. Species inhabit the northern and central parts of Europe and mountainous areas of Southern Europe; occur in the western and southern parts of Poland, also known from Ukraine. Commonly found in decayed trunks, under the protruding bark, in bundles of humus, among mosses and under trees.

Micrambe abietis (Paykull, 1798

Col.: KOC; Lit.: Łomnicki 1879, 1880, 1886; Łomnicki 1890 (Cryptophagus abietis); Łomnicki 1913;

Tenenbaum 1913; Marcu 1931; Roubal 1936.

Micrambe ulicis (Stephens, 1830)

Col.: KOC; Lit.: Łomnicki 1913 (M. vini); Tenenbaum 1913 (M. vini); 1923 (M. vini); Marcu 1929 (M. vini);

Marcu 1930 (M. vini a. villosulus); Roubal 1936 (M. vini).

Micrambe (Micrambinus) bimaculata (Panzer, 1798)

Col.: n/a; Lit.: Müller 1862 (Cryptophagus bimaculatus); Łomnicki 1913 (C. bimaculatus); Tenenbaum 1923

(C. bimaculatus); Roubal 1936 (M. bimaculatus). 


\section{Genus Ootypus Ganglbauer, 1899}

Taxonomy. Monotypic genus represented in one of the collections and in literature sources.

Distribution. Known from the southern parts of the British Isles, Fennoscandia, and Karelia to France, Switzerland, northern Italy, Serbia, and Bulgaria. Rare in Poland and Ukraine. Commonly found in the woods under the fallen leaves and among mosses and rotting fungi, also can be found in compost heaps, horse's and cow's manure, as well as rotten plant residues located in sheds and basements.

Ootypus globosus (Waltl, 1838)

Col.: MNKU, KOC; Lit.: Łomnicki 1913; Roubal 1936.

\section{Genus Paramecosoma Curtis, 1833}

Taxonomy. Monotypic genus, present in the Carpathians.

Distribution. Widespread from Scotland, the northern provinces of Fennoscandia and through all Central Europe, south of France, northern Italy, Romania (Transylvania), and Poland. In Ukraine, spread throughout the territory, except the highest mountains. Found on the banks of rivers and streams, on various plants; winters under vegetable remains, in detritus, among mosses.

\section{Paramecosoma melanocephalum (Herbst, 1793)}

Col.: ZMKU, KOC; Lit.: Łomnicki 1866, 1886; Nowicki 1873; Łomnicki 1913 (P. melanocephalum a. univestre), Marcu 1928 a; Marcu 1935 (P. melanocephalum a. obscurum, P. melanocephalum a. univestre); Roubal 1936 (P. melanocephalum f. grani, P. melanocephalum f. univestre)

\section{Genus Pteryngium Reitter, 1887}

Taxonomy. Monotypic genus, present in the Carpathians.

Distribution. Boreo-montane species, common in Fennoscandia and Karelia, in mountainous regions of Central Europe, eastern France, northern Italy, and the Balkans, also of North America. Rare in Poland and Ukraine. Occur on fungi growing on old trunks in spruce, fir, and beech forests, on fruit bodies of Fomitopsis pinicola (Sw.) P. Karst., 1881 and Polyporus P. Micheli ex Adans., 1763, found in the old bundle of humus and basiomycetes fungi growing on alder and birch trunks.

Pteryngium crenatum (Fabricius, 1798)

Col.: MNKU, KOC; Lit.: Łomnicki 1913; Roubal 1936.

\section{Genus Spavius Stål, 1862}

Taxonomy. Monotypic genus, present in the Carpathians.

Distribution. Widespread from the extreme provinces of northern Fennoscandia and most of Eastern Europe through all Central Europe to the north and east of France and northern Italy. In Ukraine, found in the western and northern regions. Live in lowland and piedmont areas; occur in the nests of F. rufa L. Imago overwinters.

Spavius glaber (Gyllenhal, 1808)

Col.: ZMKU, KOC; Lit.: Nowicki 1873 (Emphylus); Łomnicki 1886 (Emphylus); Łomnicki 1913 (Emphylus); Tenenbaum 1913 (Emphylus); Roubal 1936 (Emphylus).

\section{Genus Sternodea Reitter, 1875}

Taxonomy. Eight described species, only one Carpathian species is represented in museum collections (SMNH and KOC), also known from literature sources.

Distribution. Palearctic and Neotropics. In south-eastern Europe, reach the north-eastern part of the Ukrainian Carpathians. In the territory of Poland, Slovakia, and Ukraine occur rarely. Live in mountainous and piedmont regions; bide under the fallen leaves, in detritus and in trunks of old trees.

Sternodea baudii Reitter, 1875

Col.: SMNH, KOC; Lit.: Łomnicki 1913; Roubal 1936. 


\section{Genus Telmatophilus Heer, 1841}

Taxonomy. Nine species in the genus, 4 of them present in the Carpathian region.

Distribution. European species spread from the Mediterranean, Spain, Italy, and Macedonia through the central part of the continent to the southern parts of the British Isles and Fennoscandia. In Ukraine, found in lowland and hilly areas throughout the country, but basically, the data relate to the last century. In the Carpathians, represented by four species, but only two of them were recorded by the author. Live on the banks of standing water bodies. The larvae development occurs inside the inflorescences of sedge Carex L., rhizosphere - Typha L., and sparganium - Sparganium L. Larvae develop during June-July, until August, and young imago appear in mid-to-late August. Imago overwinters in detritus, under plant remains.

\section{Telmatophilus brevicollis Aubé, 1862}

Col.: ZMKU, MNKU; Lit.: Łomnicki 1913; Marcu 1935 (Telmatophilus brevicollis a. rufus); Marcu 1936; Roubal 1936.

Telmatophilus caricis (Olivier, 1790)

Col.: MNKU, KOC; Lit.: Nowicki 1873; Łomnicki 1875, 1886, 1890, 1913; Tenenbaum 1913; Roubal 1936.

Telmatophilus sparganii (A. Ahrens, 1812)

Col.: SMNH; Lit.: Łomnicki 1913; Marcu 1930; Roubal 1936.

Telmatophilus typhae (Fallén, 1802)

Col.: ZMKU, KOC; Lit.: Łomnicki 1891; Łomnicki 1913 (T. typhae var. pumilus and T. schöherri); Marcu 1936 (schöherri); Roubal 1936 (schöherri = T. schoenherii).

\section{Results}

In the text we will consider the most important and relevant issues: 1) attention to silken-fungus beetles as objects of research interest and collecting, 2) specifics of the regional fauna; 3) completeness and changes in the faunal list, 4) analysis of the abundance of the group in the context of identifying highly rare species.

\section{Carpathian Cryptophagidae as an object of special attention}

Researchers' attention to the Cryptophagidae of Ukraine has always been insignificant, especially in relation to the fauna of the Ukrainian Carpathians. In fact, after the works of O. Marcu on Bukovina and the surrounding territories of Romania, and J. Roubal on Slovakia and the territory of modern Zakarpattia Oblast, which were published in the early 1920s and 1930s, no special research was conducted, except for brief mentions of species of the family in reviews of Coleoptera of the region (e.g. Chumak et al. 2015). As an object of collection, this group also proved to be "inconvenient" due to small body size and special efforts needed to collect and identify specimens, often much larger than the efforts of other groups of beetles.

One of the works of the assemblage "Saproxylic Beetles - Their Role and Diversity in European Woodland and Tree Habitats" (Nitzu 2009) indicates a fairly large proportion of species of the studied family, but in the discussion the author does not provide any data on species composition or any information about the role of this family in trophic relationships. In this work on edaphic species of Coleoptera, they mentioned three species of the genus Cryptophagus (Nitzu 2008) as single specimens.

\section{About the completeness and changes in the list of fauna}

Indicators of the actual and expected richness of the silken-fungus beetle fauna in order of systematic groups show the greatest species diversity in the genera Cryptophagus and Atomaria, which are also the most numerous in the family. In addition, 4 genera such as Spavius, Pteryngium, Paramecosoma, and Ootypus, are monotypic in general, in addition, the genus Sternodea is represented at the regional level by one species (S. baudii). Rare and unique species will be included in a separate publication in the near future. 
Within the Carpathian fauna, the family includes 116 species of beetles, which follows from the sum of three data sources: the author's research, processing of collections of zoological museums, and literature analysis. Of these, 78 species are confirmed by voucher specimens. According to a preliminary revision, the volume of the regional fauna of Cryptophagidae of the Ukrainian Carpathians was estimated at 116 species (Ocheretna 2015). The number " 116 " is obtained on the basis of a detailed analysis of the whole array of special scientific publications, current lists of Fauna Europaea (Jong et al. 2014; Otero et al. 2018) and other sources. From this complete reconstructed list, the descriptions that allow to refer the species to the fauna of the Ukrainian Carpathians have 116 species, taking into account all the literature clarifications and factual data.

Taking into account indirect data (ambiguous indications, not confirmed by descriptions or collection specimens, lost labels, findings in adjacent territories) there are 78 confirmed species; the remaining 38 are known only from literature sources, in particular 8 of them are found exclusively in the literature without factual material, and the remaining 30 are presented in one or more collections, but not from the Carpathian region. The presence of about 10-15 more species is assumed on the basis of data on their distribution in adjacent territories (including the territories of neighbouring countries) from literature sources. Examples of such species are:

- Atomaria scutellaris, A. unifasciata, and Caenoscelis sibirica: assumptions on indications from the territory of Ukraine and Slovakia based on the work by J. Roubal (Roubal 1936);

- Atomaria basalis, A. norica, A. unifasciata, A. nigripennis, Cryptophagus hexagonalis, C. puncticollis, and C. simplex: assumptions based on the works of M. Łomnicki and M. Nowicki for the territory of Ukraine and Poland (Nowicki 1873; Łomnicki 1886, 1913);

- Atomaria gibbula: assumptions based on the works of O. Marcu from Romania and the adjacent territory of Ukraine and Romania (Marcu 1930).

It is obvious that each new stage of research allows to reveal more and more new species. This progress is determined by two groups of factors:

1) changes in our knowledge, including: 1a) research coverage of new previously unexplored areas, habitats, mountains, etc., and 1b) changes in the taxonomy of the group, i.e. changes in our knowledge on the composition of fauna, examples of which are noted above: 8 species as a supplement to the list of the region's fauna;

2) actual changes in the fauna itself, which are caused by: $2 a$ ) appearance of species new for the region (including due to natural expansion and accidental anthropochory), and 2b) possible extinction of other species due to restricted distribution, destruction of typical habitats, and other processes.

Currently, we can only conclude the growth of the list of species, in particular due to factor 1a, the role of factor $1 \mathrm{~b}$ is smaller, and in fact there is no influence (at the current level of knowledge about the fauna of this group of insects in the Carpathians) of factors $2 \mathrm{a}$ and $2 \mathrm{~b}$. We can expect a further increase in the list of Cryptophagidae species with the expansion of research on the northern main slopes of the Carpathians, and Bukovina, in particular, as well as a more detailed analysis of the collections of O. Marcu and K. Penecke (ZMKU) and new collections.

\section{Rarities}

Few of the Carpathian or European "red" lists include members of the family Cryptophagidae. In particular, there are no silken-fungus beetles either in the European Red List of Saproxylic Beetles (Nieto 2010) or in the Red Book of the Ukrainian Carpathians (Mateleshko \& Potish 2011). The only exception is the Polish Red List of Animals (Banaszak et al. 2002; Pawlowski et al. 2002), although the species included have a low status: "indeterminate" and "little known" (7 species of the genera Hypocoprus, Cryptophagus, Atomaria, and Sternodea).

In further work with materials and estimating the frequency of occurrence of species in nature and their portion in the collections, it will be possible to consider the proposals for determining the 
status of rarity of some species of the family in the Ukrainian Carpathians. At present, it is possible to assume unequivocally the rarity of only a few species, in particular:

- Cryptophagus lapponicus is a rare alpine species known from Northern Europe, mainly from Fennoscandia, found in the nests of squirrels, magpies, and crows, under the protruding bark and in wood fungi; in the Carpathian region mentioned in the work of M. Łomnicki (Łomnicki 1913) and in the catalogue of beetles by J. Roubal (Roubal 1936); 75 specimens are in the author's collection (9 specimens from Uzhhorod Raion, 66 from Volovets and Mizhhirya Raions).

- Atomaria alpina is a boreo-montane species, topically and trophically closely related to the fungi Fomes fomentarius and Phellinus igniarius; for the Carpathian region, the species was mentioned in the work of M. Łomnicki (Łomnicki 1913) and the catalogue of beetles by J. Roubal (Roubal 1936); there are two specimens of the species in the author's collection from Perechyn Raion.

\section{Acknowledgements}

The author sincerely thanks the colleagues for their help in processing materials of zoological collections, in particular V. Rizun (SMNH, Lviv), M. Bilyashivsky (ZMKU, Kyiv), and O. Drogvalenko (MNKU, Kharkiv). My thanks to my scientific advisor V. Korneev (Institute of Zoology NAS of Ukraine, Kyiv) for assistance in organising the study and editors I. Zagorodniuk and Z. Barkaszi (National Museum of Natural History NAS of Ukraine, Kyiv) for the assistance in preparing the article for publication.

\section{References}

Akimov, I. A., V. A. Kharchenko, A. V. Puchkov, M. D. Zerova, L. A. Kolodochka, V. V. Anistratenko, V. M. Fursov, L. S. Cherney, O. M. Levchuk. 2016. Scientific fund collections of I. I. Schmalhausen Institute of Zoology, NAS of Ukraine. Proceedings of the National Museum of Natural History, 14: 95-108. (In Ukrainian)

Banaszak, J., R. Bernard, C. Blaszak. 2002. Czerwona lista zwierzat ginacych i zagrożonych w Polsce, Suplement. Ed. Z. Głowaciński. Wydawnictwo Instytutu Ochrony Przyrody PAN, Kraków, 1-74. https://bit.ly/2TFLhPw

Burakowski, B., M. Mroczkowski, J. Stefańska. 1986 a. Chrząszcze - Coleoptera. Cucujoidea, część 1. Katalog Fauny Polski, 23 (12): 1-265.

Burakowski, B., M. Mroczkowski, J. Stefańska. 1986 b. Chrząszcze - Coleoptera. Cucujoidea, część 1. Katalog Fauny Polski, 23 (13): 1-277.

Burakowski, B., M. Mroczkowski, J. Stefańska. 1987. Chrząszcze - Coleoptera. Cucujoidea, część 1. Katalog Fauny Polski, 23 (14): 1-308.

Buse, J., K. N. A. Alexander, T. Ranius, T. Assmann. 2009. Saproxylic Beetles - Their Role and Diversity in European Woodland and Tree Habitats (Proceedings of the 5th Symposium and Workshop on the Conservation of Saproxylic Beetles). Pensoft Publishers, 1-236. (Series: Pensoft Series Faunistica, No. 89)

Carpaneto, G. M., C. Baviera, A. B. Biscaccianti, P. Brandmayr, A. Mazzei, M. Franco, A. Battistoni, C. Teofili, C. Rondinini, S. Fattorini, P. Audisio. 2015. A Red List of Italian saproxylic beetles: taxonomic overview, ecological features and conservation issues (Coleoptera). Fragmenta Entomologica, 47: 53-126.

Cherkunov, N. 1889. List of beetles found in Kyiv and its environs. Notes of the Kyiv Society of Naturalists, 10 (1): 147-204. (In Russian)

Chumak, M. V., O. Y. Mateleshko, V. O. Chumak, M. V. Varyvoda, I. V. Hrytsiuk, A. M. Zamoroka, V. V. Mirutenko, V. I. Nazarenko, T. V. Nikulin, A. A. Petrenko, V. B. Rizun, G. V. Seredyuk, T. I. Sergi, V. B. Tymochko, E. V. Turys, T. P. Yanytsky. 2015. Taxonomic composition of the saproxylic Coleoptera (Arthropoda: Insecta) fauna in Uholka division of Carpathian Biosphere Reserve. Scientific Bulletin of the Uzhgorod University (Series Biology), 38-39: 5-11. (In Ukrainian)

Convention On Biological Diversity, 1992. www.cbd.int, 1992-2020.

Freude, H., K. W. Harde, G. A. Lohse. 1967. Familie: Cryptophagidae. Die Käfer MitteleuropaS. Goecke \& Evers, Krefeld, 7 (55): 110-158.

Geriak, Y. M., I. V. Skilsky. 2017. Contribution of Orest Marku to study of entomofauna in Bukovina. In: I. V. Skilsky, A. V. Yuzyk (eds). Oblastal Aspects of Floristic and Faunistic Research, Issue 4. Druk Art, Chernivtsi, 281-283. (In Ukrainian)

Global Taxonomy Initiative (GTI). The Convention on Biological Diversity. 1998-2018. http://www.cbd.int/gti/ Jong de, Y., M. Verbeek, V. Michelsen, P. de P. Bjørn, W. Los, F. Steeman, N. Bailly, C. Basire, P. Chylarecki, E. Stloukal, G. Hagedorn, F. T. Wetzel, F. Glöckler, A. Kroupa, G. Korb, A. Hoffmann, C. Häuser, A. Kohlbecker, A. Müller, A. Güntsch, P. Stoev, L. Penev. 2014 Fauna Europaea - all European animal species on the web. Biodiversity Data Journal, 2: e4034.

Leschen, R. A. 1996. Phylogeny and revision of the genera of Cryptophagidae (Coleoptera: Cucujoidea). The University of Kansas Sciece Bulletin. Lawrence, 55 (15): 549-634. 
Liashyna, K. 2016. The prevalence and seasonal multitude dynamics of species of the family Cryptophagidae (Cucujidae, Coleoptera) of deciduous forests of foothills of the Ukrainian Carpathians. Visnyk of the Lviv University. Series Biology, 72: 161-167. (In Ukrainian)

Liashyna, K. 2018. Silken-fungus beetles of the genus Cryptophagus (Coleoptera, Cucujoidea, Cryptophagidae) of the Borzhava ridge of Ukrainian Carpathians. Visnyk of the Lviv University. Series Biology, 77: 137-141. (In Ukrainian).

Liashyna, K. 2019. Beetles of the Cryptophagidae family as indicators of forests preservation: data analysis on tree stands of the botanical garden of Uzhgorod University. Current state and prospects of development of landscape architecture, garden and park economy, urban ecology and phytomelioration. Lviv, 269-270.

Löbl, I., A. Smetana. 2007. Catalogue of Palaearctic ColeopterA. Vol. 4. Elateroidea - Derodontoidea Lymexyloidea - Cleroidea - Cucujoidea. Apollo Books, Stenstrup, 1-935.

Łomnicki, M. 1866. Przyczynek do fauny chrzaszczów galicyjskich. Kraków, 1-9.

Łomnicki, M. 1868. Wycieczka na Czarnogórę. Sprawozdanie Komisyi Fizyjograficznej. Kraków, 2: 132-152.

Łomnicki, M. 1870. Zapiski z wycieczki podolskiej odbytej w roku 1869 pomiędzy Seretem, Zbruczem a Dniestrem. Sprawozdanie Komisyi Fizyjograficznej. Kraków, 4: 41-85.

Łomnicki, M. 1875. Chrzaszcze zebrane w okolicy Stanislawowa. Sprawozdanie komisyi fizyjograficznej. Kraków, 10: $154-184$.

Łomnicki, M. 1877. Wykaz chrząszczów nowych dla fauny galicyjskiej. Sprawozdanie Komisyi Fizyjograficznej. Kraków, 11: 151-152.

Łomnicki, M. 1879. Wykaz chrząszczów nowych dla fauny galicyjskiej. Sprawozdanie Komisyi Fizyjograficznej. Kraków, 13: 221-223.

Łomnicki, M. 1880. Chrząszcze zebrane w górach Sołotwińskich. Sprawozdanie Komisyi Fizyjograficznej. Kraków, 14: 3-12.

Łomnicki, M. 1886. Muzeum imienia Dzieduszyckich we Lwowie. Dział 1. Zoologiczny oddział zwierząt bezkręgowych. Chrząszcze (Coleoptera). Lwów, 1-77.

Łomnicki, M. 1890. Fauna Lwowa i okolicy. 1. Chrząszcze (Coleoptera). (Tęgoskrzydłe). Cz. 1. Sprawozdanie Komisyi Fizyjograficznej. Kraków, 25: 141-217.

Łomnicki, M. 1891. Wykaz chrząszczów nowych dla fauny Galicyi. Sprawozdanie Komisyi Fizyjograficznej. Kraków, 26: 16-25.

Łomnicki, M. 1913. Wykaz chrząszczów czyli Tęgopokrywych (Coleoptera) ziem polskich. (Catalogus coleopterorum Poloniae). Kosmos, seria A - biologia, 21-155.

Lyubarsky, G. Yu. 1998. Phylogenetics of beetles from family Cryptophagidae (Coleoptera): a gradistic analysis. Moscow Univ. Press, Moskva, 1-92. (Series: Zoological Research; Issue 1). (In Russian)

Lyubarsky, G. 1999. Cryptophagidae (Coleoptera) from the Himalayas, with descriptions of new species, keys and remarks to some Languriidae. Stuttgarter Beitrage zur Naturkunde. Ser. A (Biologie), 598: 1-27.

Lyubarsky, G. Yu. 2002. Cryptophaginae (Coleoptera: Cucujoidea: Cryptophagidae): Diagnostics, Chorology, Ecology. Moscow Univ. Press, Moskva, 1-421. (Series: Proceedings of Zool. Museum of Mosk. Univ.; Vol. 43). (In Russian)

Lyubarsky, G. Yu., E. E. Perkovsky. 2011. Third contribution on Rovno amber silken fungus beetles: a new Eocene species of Cryptophagus (Coleoptera, Clavicornia, Cryptophagidae). ZooKeys, 130: 255-261.

Lyubarsky, G. Y., E. E. Perkovsky. 2012. The first Eocene species of the genus Cryptophagus (Coleoptera, Clavicornia, Cryptophagidae). Vestnik zoologii, 46 (1): 83-87.

Marcu, O. 1928 a. Zur Kenntnis der Koleopterenfauna der Bukowina. Verhandlungen und Mitteilungen des Siebenburgischen Vereins fur Naturwissenschaften in Hermannstadt, 78: 31-40.

Marcu, O. 1928 b. Contribuţiuni la cunoaşterea Coleopterelor Olteniei. Arhivele Olteniei, 7 (39-40): 488-490.

Marcu, O. 1929. Neue Koleopterenfunde aus der Bucovina. Buletinul Facultatii de Stiinte din Cernauti, 3: 160170.

Marcu, O. 1930. Weitere Coleopterenfunde aus der Bucovina.Bulletin de la Section Scientifique de I'Academie Roumaine, 13: 248-254.

Marcu, O. 1931. Weitere neue Coleopterenfunde aus der Bucovina. Bulletin de la Section Scientifique de I'Academie Roumaine, 14: 1-7.

Marcu, O. 1933. Zur Coleopterenfauna der Bucovina.Bulletin Sectiunea Sciintifica (Academia Roumaine), 16: $1-10$.

Marcu, O. 1935. Zur Kenntnis der Coleopterenfauna von Rumanien, nebst Beschreibung einiger neuen palaarktischen Formen. Buletinul Facultatii de Stiinte din Cernauti, 8: 90-96.

Marcu, O. 1936. Coleopterenfunde aus der Bucovina. Verhandlungen und Mitteilungen des Siebenbürgischen Vereins für Naturwissenschaften,15-16: 56-83.

Mateleshko, O. Yu., L. A. Potish. 2011. Red Data Book of the Ukrainian Carpathians. Animal World. Karpaty Press, Uzhhorod, 1-336. (In Ukrainian)

Miller, L. 1867. Eine entomologische Reise in die ostgalizischen Karpathen. Verh. Zool.-Bot Ges. Wien, 18: 3-34.

Müller, J. 1862: Verzeichnis der bis jetzt in Mähren und Oesterreich-Schlesien aufgefundenen Coleopteren. Verh. Naturforsch. Ver. Brünn, 1: 211-245.

Nieto, A., K. N. A. Alexander. 2010. European Red List of Saproxylic Beetles. Publications Office of the European Union, Luxembourg, i-viii + 1-44. 
Nitzu, E., A. Nae, I. Popa. 2008. The fauna of soil beetles (edaphic Coleoptera) as a sensitive indicator of evolution and conservation of ecosystems. A study on the altitudinal gradient in the Rodnei Mountains Biosphere Reserve (the Carpathians). Advances in Arachnology and Developmental Biology. Vienna, Belgrade, Sofia Monogr., 12: 405-417.

Nitzu, E., N. Olenici. 2009. The first study on the beetle fauna in the Giumalau spruce primeval forest (Eastern Carpathians, Romania), mainly based on a quantitative analysis of terrestrial and saproxylic species. Saproxylic Beetles - Their Role and Diversity in European Woodland and Tree Habitats (Proceedings of the 5th Symposium and Workshop on the Conservation of Saproxylic Beetles). Pensoft Publishers, 1-236. (Series: Pensoft Series Faunistica, No. 89).

Nowicki, M. 1864. Przyczynek do owadniczej fauny Galicji. Kraków, 1-87.

Nowicki, M. 1865. Insecta Haliciae Musei Dzieduszyckiani. I. Coleoptera. Chrabaszcze. Cracoviae, 7-47.

Nowicki, M. 1873. Verzeichniss galizischer Käfer. Beiträge zur Insektenfauna Galiziens. Krakau, 7-52.

Ocheretna, K. V. 2015. Historical information on the state of study of the fauna of silken-fungus beetles (Coleoptera: Cryptophagidae) in Ukraine. The Contribution of Naturalists-Lovers to the Study of Biological Diversity. International Scientific Conference, Dedicated to the 200th Anniversary of the birth of L. Wagner. Berehovo, 475-479. (In Ukrainian)

Ocheretna, K. 2019 a. Beetles of the family Cryptophagidae (Coleoptera) in the collection of Zoological Museum of Taras Shevchenko National University of Kyiv. Ukrainian Entomological Journal, 17 (2): 10-24.

Ocheretna, K. 2019 b. Cryptophagidae (Coleoptera) in the collections of Ukraine: species, specimens, and collectors. Proceedings of the State Museum of Natural History, 35: 21-36.

Ocheretna, K. 2019 c. Cryptophagidae (Coleoptera) in Volodymyr Lazorko's collection stored at Schmalhausen Institute of Zoology (Kyiv, Ukraine). Geoß Bio, 17: 62-76.

Ocheretna, K. 2019 d. Johann Hochhuth and his collection of silken-fungus beetles (Coleoptera: Cryptophagidae): significance and unique specimens. GeoઐBio, 18: 139-146.

Ocheretna, K. 2019 e. Naturalist Johann Heinrich Hochhuth and his collection of Cryptophagidae (Coleoptera: Cucujoidea). In: I. Zagorodniuk (Ed.). Natural History Museology. Volume 5 (Natural History Museums in Ukraine). NMNH NAS of Ukraine, Kyiv, 78-81. (In Ukrainian)

Otero, J. C. 2013. Cryptophaginae (Coleoptera) de la región Paleárctica Occidental. Asociación Europea de Coleopterología. Barcelona, 1-299. (Series: Coleopterological monographs. Barcelona; Vol. 4).

Otero O., P. Audisio, C. Pasqual, I. Kovar, B. J. van Vondel. 2018. Cryptophagidae. ColeopterA. Fauna Europaea, version 2018.11.

Pawlowski, J., D. Kubizh, M. Mazur. Coleoptera. Chrząszcze. In: Głowaciński Z. (red.) 2002. Czerwona lista zwierząt ginacych i zagrożonych w Polsce. Instytut Ochrony Przyrody PAN, Kraków, 88-100.

Peris, D., G. Y. Lyubarsky, E. E. Perkovsky. 2017. A new genus of silken-fungus beetle (Coleoptera: Cryptophagidae) from the Spanish Cretaceous amber. Cretaceous Research, 78: 191-195.

Pundiy, P., M. Kozak. 2016. Lazorko, Volodymyr. Encyclopedia of Modern Ukraine. online: http://esu.com.ua/ search_articles.php?id=53049

Reitter, E. 1909. Cryprophagidae. Fauna GermanicA. Die Käfer des Deutschen Reiches. K. G. Lutz Verl., Stuttgart, 3: $54-73$.

Reška, M. 1994: Bestimmungstabellen der mitteleuropäischen Arten der Gattungen Micrambe Thomson und Cryptophagus Herbst (Insecta: Coleoptera: Cryptophagidae). Annalen des Naturhistorischen Museums in Wien. Serie B für Botanik und Zoologie, 96: 247-342.

Roubal, J. 1930. Katalog Coleopter (broùku) Slovenska a Podkarpatska. Praha, 1: 1-527.

Roubal, J. 1936. Katalog Coleopter (broưku) Slovenska a Podkarpatské Rusi. Praha, 2: 1-434.

Roubal, J. 1941. Katalog Coleopter (broůku) Slovenska a Východních Karpat. Praha, 3 (1937-1941): 1-321.

Tenenbaum, Sz. 1913. Chrząszcze (Coleoptera) zebrane w Ordynacyi Zamojskiej w gub. Lubelskiej. Pamiętnik Fizyograficzny, 21 (3): 1-72.

Tenenbaum, Sz. 1923. Przybytki do fauny chrząszczów Polski od roku 1913. Rozpr. Wiad. Muz. Dzied., 7-8: $136-186$.

Tenenbaum, Sz. 1938. Nowe dla Polski gatunki i odmiany chrząszczy. Fragmenta Faunistica Musei Zoologici Polonici. Warszawa, 3: 415-429.

Tsinkevich, V. A. 2005. Checklist of Cucujoidea (Coleoptera) of Belarus (Eastern Europe). Contributions to Systematics and Biology of Beetles. (Papers celebrating the 80th birthday of Igor Lopatin), 333-345.

Zagorodniuk, I., I. Shydlovskyy. 2014. Acronyms for zoological collections of Ukraine. In: Zagorodniuk I. (ed.). Zoological Collections and Museums. NMNH NAS of Ukraine. Kyiv, 33-43. (In Ukrainian)

Zagorodniuk, I. 2016. Natural history collections in the Kyiv Pedagogical Museum in 1902-1917. Proceedings of the National Museum of Natural History, 14: 123-135. (In Ukrainian) 